ELORE (ISSN 1456-3010), vol. 19 - 2/2012.

Julkaisija: Suomen Kansantietouden Tutkijain Seura ry.

[http://www.elore.fi/arkisto/2_12/raninen-siiskonen.pdf]

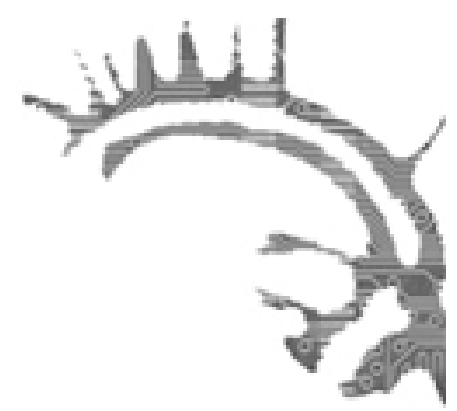

\title{
KIRJA-ARVIO
}

\section{KARJALAA EDESTAKAISIN}

FINGERROOS, OUTI \& HÄYRYNEN, MAUNO (toim.) 2012: Takaisin Karjalaan. Suomalaisen Kirjallisuuden Seuran Toimituksia 1250. Helsinki: SKS. 223 sivua.

\section{Tarja Raninen-Siiskonen}

Kiinnostus Karjalaa kohtaan ei ole laantunut, vaikka jatkosodan päättymisestä tulee piakkoin kuluneeksi 70 vuotta. Takaisin Karjalaan -kirjan artikkelien yhteisenä nimittäjä on kirjan toimittajien mukaan keskittyminen lähihistoriaan ja luovutettuun Karjalaan. Heidän tarkoituksenaan on popularisoida aiempaa tutkimusta, mutta esitellä myös uusia tuloksia ja hakea yhteyksiä teemojen välille. Uusia Karjala-tutkimuksia on riittänyt, koska aihe kerää maassamme vielä toistaiseksi laajan lukijakunnan. Pari vuotta sitten Karjalan Liiton juhlaseminaarissa silloinen pääministeri Matti Vanhanen arvioi, että jopa miljoonalla suomalaisella on sukujuuret luovutetussa Karjalassa! Aihe siis koskettaa kansalaisia.

\section{EVAKOIDEN TOIVEITA}

Kirja on jaettu kolmeen temaattiseen osioon, joista ensimmäisessä pohditaan Karjalaa koskevaa haaveellista retoriikkaa ja toisessa Karjalan vierautta. Kolmannessa osiossa Karjalaa lähestytään empaattisesta näkökulmasta käsin. Ensimmäisen osan nimi, "Haave", kertoo kirjoittajien sukupolvesta. Evakkouden kokenut sukupolvi olisi nimennyt osion pikemminkin "toiveeksi", sillä palautukseen uskottiin hyvin pitkään. Kirjan aloittavat 
Outi Fingerroosin ja Markku Kangaspuron artikkelit, jotka sopivat mutkattomasti yhteen. Alkajaisiksi Fingerroos tuo esiin Karjalan kysymyksen kolme aaltoa ja osoittaa kuinka Karjalan käsite on säilyttänyt poliittisen leiman Suomessa. August Vilhem Ervastin vuonna 1897 esittämistä Karjalan teeseistä muotoutui karelianismin poliittinen aate, joka vaikutti myös 1900-luvulla nousseen Karjalan kysymyksen taustalla. Karjalan kysymyksellä tarkoitetaan keskustelua Neuvostoliitolle luovutettujen alueiden palautuksesta Suomelle. Kysymys Karjalasta uinui sotien jälkeen julkisuudelta piilossa näyttäen ulospäin pitkältä hiljaisuudelta, kunnes 1990-luku ja Baltian maiden itsenäistyminen aloittivat Karjalan palautuskeskustelun uudelleen.

Markku Kangaspuro pureutuu artikkelissaan Kainuun Sanomien uutiseen vuodelta 2007, jossa otsikoitiin Karjalan olleen kaupan vuonna 1991. Tuona aikaa Suomen halu päästä eroon YYA-sopimuksesta ja liittyä EU:n jäseneksi ohjasivat valtiovallan toimia kuitenkin niin, ettei rajakysymykseen haluttu puuttua. Kangaspuron mukaan Karjalan kysymys nousee esiin, koska Karjala on toiminut Suomessa kansallisen identiteetin rakennusaineena ja koska Karjalan menetys koettiin vääryytenä. Keskustelua Karjalan omistuksesta ja palautuksesta ruokki myös se, ettei suomalaispoliitikkojen neuvottelutaitoihin luotettu, vaan heidän uskottiin olevan "rähmällään" Venäjän edessä.

\section{KARJALA VENÄLÄISTEN OMISTUKSESSA}

"Vieras Karjala"-osio tuo teoksessa eniten uutta tietoa esiin. Tarkastelun kohteena ovat luovutettuun Karjalaan asettuneet venäläiset ja heidän sopeutumisensa. Pekka Hakamiehen artikkeli pohjautuu haastatteluihin, joita hän teki pietarilaiskollegoidensa kanssa Räisälässä, Lahdenpohjassa ja Kurkijoella. Tutkijat haastattelivat alueille sotien jälkeen saapuneita venäläisiä, joista suurin osa oli valkovenäläisiä ja tšuvasseja. Uusien asukkaiden näkökulmasta alue identifioitui sotien jälkeen Suomena, ei Karjalana. Aivan kuten karjalainen siirtoväki rajan Suomen puolella, myöskään luovutettuun Karjalaan muuttaneet venäläiset eivät pitäneet uutta asuinaluettaan heti kotiseutuna. Kotiseudun koettiin olevan siellä, mistä oli lähdetty. Karjalaisen siirtoväen kohdalla uuden asuinalueen haltuun ottamista helpotti alueen muu väestö, joka kertoi alueen historiasta. Luovutettuun Karjalaan muuttaneilla venäläisillä ei ollut vastaavaa tietoa alueen suomalaisesta historiasta tai paikannimistä. Venäläiset alkoivat käyttää uusista asuinalueistaan neuvostotyylisiä kolhoosien nimiä tai nimetä niitä venäläisten uudisasukkaiden mukaisesti. Yksi vaihtoehto oli myös arvuutella, keitä tietyssä paikassa oli asunut suomalaisajalla. Tämän lisäksi suomalaisten ja venäläisten tapa asua ja hankkia toimeentulonsa esimerkiksi maataloudesta poikkesivat toisistaan. Venäläiset purkivat ja siirsivät yksittäisiä taloja kyläkeskuksiin ja kyntivät sarkaojat umpeen. Tästä seurasi peltojen vettymistä ja sadon pienentymistä. Vastaavanlaisista käytännöistä on kirjoittanut myös Yury Shikalov (2011) Suojärven pitäjähistoriassa.

Vielä syvällisemmin luovutetun Karjalan sotien jälkeisiin olosuhteisiin pureutuu Netta Böök, joka kirjoittaa Kurkijoen arkkitehtuurista ja rakennusten suojelusta. Pitäjän rakennukset eivät tuhoutuneet sodassa. Kurkijoki edustaakin hyvin säilynyttä 1800-luvun 
lopun ja 1900-luvun alun miljöötä Karjalassa, minkä vuoksi sitä esitetään suojeltavaksi. Mielenkiintoinen kysymys on kuitenkin se, edustaako Kurkijoki suomalaista kulttuuriperintöä, koska sen rakennukset ovat suomalaisten tekemiä, vai venäläistä kulttuuriperintöä, koska sen asukkaat ovat olleet toisen maailmansodan jälkeen venäläisiä?

Matkat itärajan taakse ovat monelle elämys. Tätä matkan kokemista ja matkalla ilmeneviä tunteita kuvaa artikkelissaan Pirkkoliisa Ahponen. Hän matkasi vuonna 2007 Joensuun yliopiston opiskelijoiden kanssa Sortavalaan. Monelle heistä matka saattoi olla ensimmäinen itärajan taakse tehty. Matkalaiset kuvasivat näkemäänsä ja kokemaansa sekä tulkitsivat kokemuksiaan ja aiempaa ymmärrystään Sortavalasta. Rajan ylitys lienee ollut opiskelijoille pienoinen kulttuurišokki: vaikka Sortavala on lähellä Joensuuta, siellä on kuitenkin hyvin erilaista.

\section{OMAKOHTAISIA KOKEMUKSIA}

Kirjan viimeisessä osiossa pohditaan Karjalaa tunteiden ja kokemusten näkökulmasta teemalla "Empaattinen uusi Karjala". Anna-Kaisa Kuusisto-Arponen pohtii evakkotietä ja evakkoutta kulttuurisena traumana sekä henkisen ja fyysisen liikkeelläolon kokemuksina käsittelemällä evakkovaelluksia, joilla menneisyyden evakkomatkaa muistellaan. Hän osallistui vuonna 2006 Virolahdella järjestettyyn evakkovaellukseen lapsensa kanssa. Vaelluksen yhtenä tavoitteena oli ylittää sopeutumista ja selviytymistä korostavat tarinat. Kirjoittajan mukaan siirtokarjalaisten selviytymisen korostamiseen ja jaettuun kulttuuriseen traumaan perustunut yhteisö on hajoamassa, minkä lisäksi yhteisön kaipuun kohde on muuttunut. Fyysisen paikan ikävöinnin tilalle on tullut ajatus paikasta luopumisesta. Evakkovaelluksella tuli esiin myös se, kuinka muistelu kohdistui Karjalan kotipaikan jättämisen prosessiin.

Jaana Loipponen tuo Karjala-keskusteluun käsitteen Karjalan taju, jolla hän viittaa tutkijan sisäiseen pakkoon tutkia siirtokarjalaisuutta sekä itsensä että sukunsa vuoksi: "meidän on ollut pakko tutkia siirtolaisuuden ilmentymiä jo perheemme ja sukumme tarinoiden takia" (s.177). Artikkelissa hän pohtii omaa suhdettaan Karjalaan ja sen tutkimiseen.

Kirjan päättää Outi Fingerroosin artikkeli ylirajaisesta karjalaisesta kulttuuriperinnöstä. Ylirajaisuudella hän tarkoittaa, Steven Vertoveciin viitaten, "kansallisvaltioiden ylittäviä prosesseja ja suhteita, joissa keskeisessä roolissa ovat ei-valtiolliset toimijat" (s. 202). Fingerroos katsoo, että ylirajainen karjalainen kulttuuriperintö on ollut kiinteä osa maamme historiaa ensimmäisestä sortokaudesta lähtien. Karjalaisena kulttuuriperintönä kirjoittaja pitää niin aineellista kuin aineetontakin kulttuuriperintöä, mutta myös yksilöitä ja heidän kokemuksiaan, historiantutkimuksia ja -kirjoituksia sekä tapaamme toimia eri aikoina.

Kirjassa on myös pieniä, pääasiassa Katariina Kososen kokoamia tietolaatikoita kuvineen Karjalasta. Tietolaatikoiden sisällöt avaavat mukavasti eri artikkeleita, mutta niiden sijainti artikkelien keskellä häiritsee hieman. 
Tarja Raninen-Siiskonen: Karjalaa edestakaisin

\section{KARJALA KIINNOSTAA}

Takaisin Karjalaan on mielenkiintoista luettavaa kaikille Karjalasta kiinnostuneille, vaikkakin teoksessa pysytään pitkälti Suomen kontekstissa esimerkiksi vertailematta Suomen Karjala-suhdetta sekä Karjalan historiaa globaaleihin maailmanpoliittisiin tapahtumiin. 1800-luvulla Euroopassa oli vallalla valkoisen miehen ylivaltaan perustunut siirtomaa-ajattelu, joka oikeutti eurooppalaisten valtioiden sivistyspyrkimykset Afrikan siirtomaissa. 1800-luvun lopulla nationalismin tuulet alkoivat vyöryä myös Suomeen ja synnyttää suomalaista nationalismia. Itä-Karjalaa voitaneen pitää tässä mielessä Suomen tai suomalaisten siirtomaana, jonka suhteen suomalaiset ottivat samankaltaisen sivistäjän roolin kuin mikä eurooppalaisilla oli omien siirtomaidensa suhteen. Tämänkaltaiset historialliset ja kansainväliset vertailut olisivat tuoneet monipuolistavan näkökulman myös käsillä olevaan artikkelikokoelmaan.

Kirja on tekijöidensä mukaan tarkoitettu kurssi- ja käsikirjaksi karjalaisesta kulttuuriperinnöstä kiinnostuneille. Koottua tietoa tässä toki tuleekin sekä kaikille Karjalasta kiinnostuneille että karjalaiset sukujuuret omaaville. Onkin mielenkiintoista, että Karjala-tutkimus on rajoittunut pääasiassa karjalaiseen siirtoväkeen ja sen näkökulmaan. Paikallisten vastaanottohalukkuus ei ole juurikaan noussut tutkimuksissa esiin, lukuunottamatta Heikki Wariksen tutkimusryhmän klassikkotutkimusta vuodelta 1952 ja Pirkko Sallinen-Gimplen väitöskirjaa vuodelta 1994. Kirja onkin esimerkki tekijöiden mainitsemasta Karjalan tajusta, joka ajaa tutkimaan omia sukujuuria ja oman suvun kohtaloita.

\section{KirJallisuUs}

SALLINEN-GIMPL, PIRKKO 1994: Siirtokarjalainen identiteetti ja kulttuurien kohtaaminen. Helsinki: Suomen Muinaismuistoyhdistys.

SHIKALOV, YURY 2011: Suojärvi toisen maailmansodan jälkeen. - Hämynen, Tapio (toim.), Omal mual - vierahal mual: Suojärven historia $I V$. Nurmes: Suojärven pitäjäseura.

WARIS, HEIKKI \& JYRKILÄ, VIENO \& RAITASUO, KYLLIKKI \& SIIPI, JOUKO 1952: Siirtoväen sopeutuminen. Tutkimus Suomen karjalaisen siirtoväen sosiaalisesta sopeutumisesta. Helsinki: Otava.

Filosofian tohtori Tarja Raninen-Siiskonen työskentelee museonjohtajana Joensuun museoissa. 